\title{
Analisis Kelayakan Isi Materi Buku Teks Bahasa Indonesia Kelas XII Terbitan Kemdikbud Edisi Revisi 2018
}

\section{Feasibility Analysis of the Contents of Indonesian Language Textbook for Class XII Published by the Ministry of Education and Culture, Revised Edition 2018}

\author{
Gita Wulandari*, Made Sri Indriani, Gede Nurjaya \\ Pendidikan Bahasa dan Sastra Indonesia, Fakultas Bahasa dan Seni, Universitas Pendidikan Ganesha \\ "Correspondence: gitawulandari19@undiksha.ac.id
}

Received: 18 October 2021; Accepted: 3 December 2021; Published: 27 December 2021

\begin{abstract}
Abstrak: Buku teks adalah salah satu media pembelajaran yang sering dipakai oleh guru. Karena itu, guru perlu paham kualitas dari sebuah buku teks. Untuk membantu guru mengetahui kualitas dari buku teks, maka diadakan analisis secara mendalam kesesuaian buku teks dengan kurikulum yang berlaku, mengenai isi materi dalam buku teks. Penelitian ini menggunakan metode deskriptif kualitatif. Subjek yang digunakan adalah buku teks Bahasa Indonesia kelas XII SMA/MA/SMK/MAK terbitan Kementrian Pendidikan dan Kebudayaan edisi revisi 2018. Sedangkan, objek penelitian yang diangkat adalah kelayakan isi materi buku tersebut. Hasil analisis menunjukan isi materi buku teks yang dianalisis masuk dalam kategori layak meskipun terdapat beberapa komponen indikator yang harus diperbaiki.
\end{abstract}

Kata Kunci: Bahasa Indonesia, buku teks, kelas XII, Kemdikbud

Abstract: Textbooks are one of the learning media that are often used by teachers. Therefore, teachers need to understand the quality of a textbook. To help teachers know the quality of the textbooks, an in-depth analysis of the suitability of the textbooks with the applicable curriculum is carried out regarding the content of the material in the textbooks. This research used the descriptive qualitative method. The subjects used were textbooks of Bahasa Indonesia kelas XII SMA/MA/SMK/MAK published by the Ministry of Education and Culture in the 2018 revised edition. Meanwhile, the object of research that was raised was the feasibility of the contents of the book. The results of the analysis show that the content of the textbook material analyzed is in the proper category although several indicator components must be improved.

Keywords: Bahasa Indonesia, textbook, the Ministry of Education and Culture, XII class

\section{PENDAHULUAN}

Belajar adalah kebutuhan setiap warga masyarakat (Rista \& Ariyanto, 2018). Belajar sendiri memiliki dua jenis, yakni formal dan nonformal. Kegiatan belajar di sekolah, yang merupakan kegiatan belajar formal, memegang peran yang sangat penting. Karena melalui kegiatan belajar di sekolah siswa akan dapat meningkatkan kualitas berpikir dan keterampilan mereka yang kreatif dan inovatif, sehingga bermanfaat bagi dirinya maupun orang lain. Semua tujuan pembelajaran itu telah termuat dalam kurikulum. Sehingga, kurikulum merupakan suatu hal yang penting dalam dunia pendidikan. Sama halnya dengan pola pikir manusia yang terus berkembang, kurikulum pun turut demikian (Fujiawati, 2016). Sebagai cara untuk mengingkatkan mutu pendidikan, Indonesia telah 
mengalami beberapa kali perubahan kurikulum. Pada tahun pembelajaran 2019/2020, kurikulum nasional yang dipakai adalah Kurikulum 2013 (K13). Menurut Ikhsan \& Hadi (2018), orientasi K13 adalah meningkatan dan menyeimbangkan kompetensi sikap, keterampilan, dengan pengetahuan.

Pandemi covid-19 membuat pembelajaran di Indonesia menjadi berbasis daring (Santoso \& Dewi, 2021). Hal tersebut membuat kurikulum yang sudah ditentukan megalami sebuah fleksibilitas sesuai dengan kondisi siswa dan sekolah. Saat ini pembelajaran daring di sekolah menggunakan sebuah kurikulum khusus yang disesuaikan dengan keadaan daring dan tetap mengacu pada K13. Adapun $\mathrm{K} 13$ yang digunakan saat ini telah disederhanakan sesuai dengan dengan sistem pembelajaran daring.

Salah satu hal yang penting dalam pembelajaran adalah keberadaan media pembelajaran. Media pembelajaran sangat dibutuhkan oleh guru demi menunjang dan mempermudah proses pembelajaran secara maksimal (Prasetyo, 2021), termasuk dalam kondisi daring. Dari banyaknya media pembelajaran yang ada, buku teks merupakan salah satu media yang komplit dan dapat membantu siswa dalam belajar secara mandiri. Menurut Tarigan \& Djago (2009), buku teks merupakan buku pelajaran dalam mata pelajaran tertentu yang merupakan buku standar, yang disusun oleh para pakar dan memuat tujuan pembelajaran dengan rinci, serta mudah dipahami oleh para pembelajar. Sehingga, buku teks akan sangat menunjang suatu pembelajaran. Ditambah lagi, buku teks yang ada sangat relevan dengan perangkat pembelajaran, seperti prota, promes, dan rpp. Gustini (dalam Sriasih, 2014) mengungkapkan, buku teks harus menjadi buku acuan wajib karena telah melalui uji kelayakan Badan Standar Nasional Pendidikan (BNSP, 2014) dan ditetapkan melalui Permendikbud RI No 1 Tahun 2015 Tentang Buku Teks Pelajaran dan Panduan Kurikulum.

Dalam hal ini, agar pembelajaran dapat membuahkan hasil yang optimal, seorang guru harus paham mengenai buku teks yang memiliki kualitas yang baik sesuai dengan kurikulum yang berlaku, serta mampu memilih buku teks dengan cermat dan teliti. Hal tersebut juga diungkapkan oleh Husen (2013), bahwa guru perlu memilih buku teks pembelajaran sesuai dengan kriteria yang baik. Lebih lanjut lagi, Sari (2019) juga menyatakan bahwa salah satu faktor yang menentukan keberhasilan guru dan siswa dalam mencapai tujuan pembelajaran ditentukan oleh kualitas buku teks yang digunakan. Maka dari itu, dapat disepakati bahwa pemilihan buku teks sangat penting dalam pembelajaran. Sehingga, penulis tertarik melakukan penelitian tentang analisis kelayakan isi materi buku teks.

Adapun buku teks yang diplih sebagai bahan kajian adalah buku Bahasa Indonesia kelas XII SMA/MA/SMK/MAK yang diterbitkan oleh menteri Pendidikan dan Kebudayan edisi revisi 2018. Buku tersebut dipilih karena sesuai dengan rumpun disiplin ilmu penulis. Selain itu, buku tersebut adalah terbitan pemerintah yang seharusnya minim kesalahan.

Berdasarkan pemaparan di atas, penulis merumuskan tujuan yang ingin dicapai dalam penilitian ini, yaitu untuk mendeskripsikan kelayakan isi materi buku teks Bahasa Indonesia Kelas XII SMA/MA/SMK/MAK Terbitan Kementerian Pendidikan dan Kebudayaan Edisi Revisi 2018 berdasarkan Badan Standar Nasional Pendidikan (BSNP). Selanjutnya, hasil dari penelitian ini diharapkan dapat menjadi rujukan dan sumber informasi yang berkontribusi dalam dunia pendidikan di Indonesia.

Penelitian sejenis yang pernah dilakukan adalah penelitian Sari (2019) yang bertujuan untuk mendeskripsikan kelayakan buku teks "Bahasa Indonesia Kelas XI SMA/MA/SMK/MAK". Lalu, penelitian kedua adalah Imamah et al. (2019) yang bertujuan mengetahui kualitas buku teks "Cerdas Berbahasa Indonesia untuk SMA/MA Kelas XI" Terbitan Erlangga. Dari kedua penelitian tersebut, ditemukan perbedaan bahwa subjek yang dianalisis tidak sama. Antara penelitian Sari (2019), Imamah et al. (2019), dan penulis menggunakan buku teks yang berbeda. Maka, dengan ini terlihat dengan jelas kebaruan yang diangkat.

\section{METODE PENELITIAN}

Metode yang digunakan dalam penelitian ini adalah deskriptif kualitatif. Menurut Prastowo (2011) penelitian kualitatif adalah jalan penelitian yang sistematis dan dipakai untuk mengkaji suatu objek pada latar alamiah tanpa adanya manipulasi di dalamnya. Pada penelitian ini, hal yang akan dipaparkan secara deskriptif adalah mengenai kelayakan isi materi dan kebahasaan dalam buku teks 
Bahasa Indonesia kelas XII SMA/MA/SMK/MAK yang diterbitkan oleh menteri Pendidikan dan Kebudayan edisi revisi 2018, sesuai dengan standar yang telah ditentukan BSNP (Badan Standar Nasional Pendidikan).

Metode Pengumpulan data yang digunakan adalah dokumentasi yang dibantu dengan instrumen lembar penelitian. Tahap pertama yang dilaksanakan untuk mendapatkan data yang relevan adalah membaca buku secara keseluruhan kemudian mengidentifikasi isi materi buku teks ke dalam lembar penilaian berdasarkan BSNP dan Pusat Perbukuan Depdiknas karena lebih relevan dan dapat diprtanggungjawabkan. Adapun bab-bab yang dianalisis dalam buku teks Bahasa Indonesia kelas XII SMA/MA/SMK/MAK yang diterbitkan oleh menteri Pendidikan dan Kebudayan edisi revisi 2018 meliputi: Bab I, Membuat Surat Lamaran Pekerjaan; Bab II, Menikmati Cerita Sejarah; Bab III, Memahami Isu Terkini Lewat Editorial; Bab IV, Menikmati Novel; Bab V, Menyajikan Gagasan melalui Artikel; dan Bab VI, Menilai Karya Melalui Kritik dan Esai.

Tabel 1. Kisi-kisi Penilaian

\begin{tabular}{|c|c|c|}
\hline Sub-aspek & Butir Komponen & Indikator \\
\hline \multirow{2}{*}{$\begin{array}{l}\text { Kesesuaian uraian } \\
\text { materi dengan } \\
\text { Standar } \\
\text { Kompetensi Inti } \\
\text { dan Kompetensi } \\
\text { Dasar } \\
\end{array}$} & Kelengkapan materi & $\begin{array}{l}\text { Memuat wacana, memuat pemahaman } \\
\text { wacana, } \\
\text { memuat fakta kebahasaan dan kesastraan, } \\
\text { dan memuat aplikasi. }\end{array}$ \\
\hline & Kedalaman materi & $\begin{array}{l}\text { Kesesuaian wacana, kualitas wacana, dan } \\
\text { kuantitas wacana. }\end{array}$ \\
\hline \multirow{8}{*}{$\begin{array}{l}\text { Kesesuaian materi } \\
\text { pendukung } \\
\text { Pembelajaran }\end{array}$} & $\begin{array}{l}\text { Kesesuaian contoh, fitur, dan } \\
\text { pelatihan }\end{array}$ & $\begin{array}{l}\text { Materi yang disajikan kekinian dan } \\
\text { mencerminkan peristiwa di Indonesia. }\end{array}$ \\
\hline & $\begin{array}{l}\text { Pengembangan penalaran dan } \\
\text { pembuktian; keterkaitan antar } \\
\text { konsep/tabel/diagram/soal }\end{array}$ & $\begin{array}{l}\text { Materi runtut dan } \\
\text { memuat soal-soal yang memiliki tingkat } \\
\text { kesulitan yang bervariasi. }\end{array}$ \\
\hline & $\begin{array}{l}\text { Keterkaitan antara konsep } \\
\text { /tabel/diagram/soal }\end{array}$ & $\begin{array}{l}\text { Adanya keterkaitan antar konsep maupun } \\
\text { anatarmateri dalam tabel, diagram, gambar, } \\
\text { contoh/soal. }\end{array}$ \\
\hline & Komunikasi & $\begin{array}{l}\text { Materi menyediakan kegiatan yang } \\
\text { mendorong siswa mengomunikasikan ide } \\
\text { dalam berbagai bentuk. }\end{array}$ \\
\hline & Pembudayaan literasi & $\begin{array}{l}\text { Materi memuat tugas yang mendorong } \\
\text { siswa berliterasi, serta mendorong peserta } \\
\text { didik aktif-kritis menganalisis teks. }\end{array}$ \\
\hline & 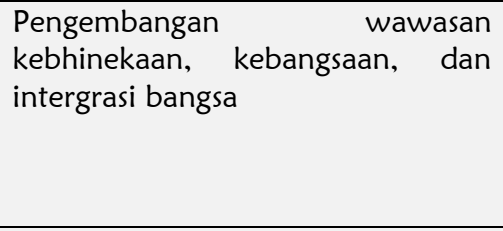 & $\begin{array}{l}\text { Materi dapat membuka wawasan siswa } \\
\text { untuk mengenal kebhinekaan, kebangsaan, } \\
\text { dan intergrasi bangsa, serta melahirkan } \\
\text { melahirkan kesadaran untuk bangga } \\
\text { menggunakan bahasa Indonesia, dan } \\
\text { memperkuat identitas bangsa Indonesia. }\end{array}$ \\
\hline & $\begin{array}{l}\text { Memperhatikan kode etik } \\
\text { penulisan dan hak cipta }\end{array}$ & $\begin{array}{l}\text { Materi merupakan karya asli atau } \\
\text { menyebutkan sumber jika mengutip. }\end{array}$ \\
\hline & $\begin{array}{l}\text { Bebas masalah } \begin{array}{r}\text { SARA, } \\
\text { pornografis/bias gender/wilayah } \\
\text { dan profesi }\end{array} \\
\end{array}$ & $\begin{array}{l}\text { Materi tidak menimbulkan masalah SARA } \\
\text { dan pornografi, serta tidak menimbulkan } \\
\text { diskriminasi. }\end{array}$ \\
\hline
\end{tabular}

Sumber: BSNP dan Pusat Perbukuan (dalam Mislia, 2018)

Tabel 2. Format Lembar Penilaian

\begin{tabular}{|c|c|c|c|c|c|c|c|c|c|c|}
\hline \multirow{2}{*}{ No } & \multirow{2}{*}{ Sub-aspek } & \multirow{2}{*}{$\begin{array}{c}\text { Butir } \\
\text { Komponen }\end{array}$} & \multirow{2}{*}{ Indikator } & \multicolumn{6}{|c|}{ Bab } & \multirow{2}{*}{ Jumlah } \\
\hline & & & & 1 & 2 & 3 & 4 & 5 & 6 & \\
\hline & & \multicolumn{9}{|c|}{ Jumlah } \\
\hline & & \multicolumn{9}{|c|}{ Persentase skor: (skor perolehan/skor maksimal) $\times 100 \%$} \\
\hline & Rangk & han dan cat & an kualitatif & aspe & 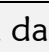 & bu & & $m$ & en & \\
\hline
\end{tabular}

Sumber: BSNP dan Pusat Perbukuan (dalam Mislia, 2018) 
Penilaian dalam penelitian ini dilakukan oleh Gita Wulandari, Mahasiswa Pendidikan Bahasa dan Sastra Indonesia Universitas Pendidikan Ganesha. Setelah mendapat persentase skor, maka selanjutnya dibaca dengan kriteria kesesuaian yang diadaptasi dari skala lima menurut Nurgiyantoro (dalam Huda, 2014). Secara lebih lengkapnya, penggolongan kelayakan yang digunakan adalah sebagai berikut.

Tabel 3. Kriteria Kesesuaian

\begin{tabular}{cc}
\hline Interval Persentase & Kriteria \\
\hline $85 \%-100 \%$ & Sangat Layak \\
$75 \%-84 \%$ & Layak \\
$60 \%-74 \%$ & Cukup Layak \\
$40 \%-59 \%$ & Kurang Layak \\
$0 \%-39 \%$ & Sangat Kurang Layak \\
\hline
\end{tabular}

Sumber: Nurgiyantoro (dalam Huda, 2014)

Teknik analisis data yang digunakan dalam penelitian ini adalah model Miles dan Huberman. Menurut Santoso et al. (2021), model ini memiliki tiga tahapan yang runtut dan sistematis, yaitu: reduksi data, sajian data, dan verifikasi. Dalam Penelitian ini, reduksi data dilakukan untuk memilih hal-hal penting yang didapatkan dalam penelitian, dan membuang hal-hal yang tidak diperlukan. Sajian data data dilakukan dengan menyajikan data yang didapat dengan cara deskripsi. Dan, verifikasi dilakukan dengan cara menarik kesimpulan dari penyajian yang telah dilakukan.

\section{HASIL DAN PEMBAHASAN}

\section{Kelayakan Isi Materi berdasarkan BSNP}

Terdapat tiga fokus inti dalam analisis kelayakan isi materi pada buku teks ini yaitu, kesesuaian materi dengan standar kompetensi (KI), keakuratan materi, dan kesesuaian materi pendukung pembelajaran. Setelah dilakukan kajian, maka diperolehlaj persentase kelayakan isi dan materi dalam buku teks yang dianalisis sebagai berikut.

$$
\text { Persentase kelayakan isi materi }=\frac{929,31}{1100} \times 100 \%=84,48 \%
$$

Berdasarkan hasil presentase tersebut, maka isi materi dalam buku teks Bahasa Indonesia kelas XII SMA/MA/SMK/MAK terbitan Kementrian Pendidikan dan Kebudayaan edisi revisi 2018 dikategorikan layak untuk digunakan dalam menunjang ketercapaian Kompetensi Inti (KI) dan Kompetensi dasar (KD). Selanjutnya, akan dipaparkan dua subaspek yang dianalisis, yakni "Kesesuaian uraian materi dengan Standar Kompetensi Inti dan Kompetensi Dasar" yang memiliki butir komponen: (1) kelengkapan materi, dan (2) kedalaman materi. Juga, subaspek "Kesesuaian materi pendukung Pembelajaran" yang memiliki butir-butir komponen: (3) kesesuaian contoh, fitur, dan pelatihan; (4) pengembangan penalaran dan pembuktian; (5) keterkaitan antar konsep/tabel/diagram/soal; (6) komunikasi (write and talk); (7) pembudayaan literasi; (8) pengembangan wawasan kebhinekaan, kebangsaan, dan intergrasi bangsa; (9) memperhatikan kode etik penulisan dan hak cipta; serta (10) bebas masalah SARA dan pornografis/bias gender/wilayah dan profesi.

Selanjutnya pemaparan keseluruhan butir-butir komponen akan dipaparkan melalui numerisasi, tanpa disebutkan subaspeknya. Hal ini dilakukan agar pembahasan dapat dipahami lebih mudah. Adapun persentase pada setiap subaspek isi materi dapat dilihat pada Gambar 1 sebagai berikut. 


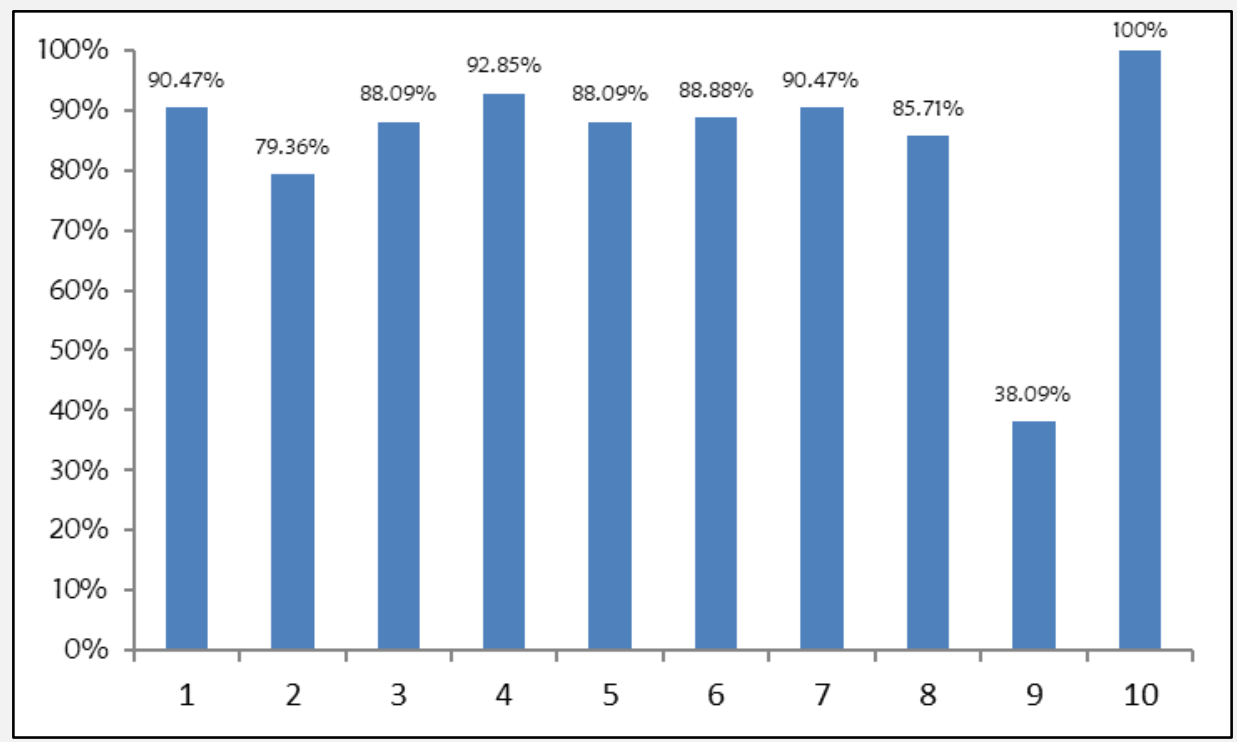

Gambar 1. Persentase Kelayakan Isi Materi

\section{Kelengkapan Materi}

Menurut Siagian (2016), materi yang disajikan dalam buku teks minimal memuat keseluruhan materi pokok bahasan dalam aspek ruang lingkup yang mendukung tercapainya standar kompetensi dan kompetensi dasar, yang telah disusun dalam kurikulum mapel yang bersangkutan. Berdasarkan data yang diperoleh penulis, kelengkapan materi dalam buku teks Bahasa Indonesia kelas XII SMA/MA/SMK/MAK terbitan Kementrian Pendidikan dan Kebudayaan edisi revisi 2018 mendapatkan persentase sebanyak $90,47 \%$, berdasarkan presentase terebut maka kelengkapan materi dalam buku teks ini dapat dikategorikan dalam predikat sangat layak, dan sudah sesuai dengan (KI) dan (KD).

Buku ini sendiri terdiri dari 6 bab meliputi, Bab I, Membuat Surat Lamaran Pekerjaan; Bab II, Menikmati Cerita Sejarah; Bab III, Memahami Isu Terkini Lewat Editorial; Bab IV, Menikmati Novel; Bab V, Menyajikan Gagasan melalui Artikel; dan Bab VI, Menilai Karya Melalui Kritik dan Esai.

Walaupun mendapat kriteria kelengkapan materi yang sangat layak, namun masih terdapat sedikit kekurangan yang perlu direvisi. Kesalahan tersebut berada pada Bab II. Berdasarkan telaah yang dilakukan, penulis tidak menemukan adanya materi yang memuat unsur-unsur teks cerita sejarah.

\section{Kedalaman Materi}

Menurut BSNP (dalam Mislia, 2018) kedalaman materi dalam buku teks dapat diamati dari ada atau tidaknya beberapa indikator berikut ini, (1) kesesuaian wacana; (2) kuantitas wacana; dan (3) kualitas wacana. Setelah dianalisis dengan berpatokan pada BNSP (2014), ditemukan indikator yang kurang lengkap. Pertama, pada bagian Bab I. Dalam hal ini, penulis hanya mencantumkan contoh surat lamaran pekerjan yang benar. Padahal, pembelajaran akan lebih jelas lagi jika dicantuman juga contoh surat lamaran pekerjaan yang salah. Selain itu, pada Bab II terdapat penggalam bacaan yang mencantumkan sampul novel, sedangkan penggalam bacaan lainnya diambil tidak disertakan. Hal ini menunjukkan ketidakkonsistenan dalam kedalaman materi. Meskipun demikian, kedalaman materi dalam buku ini mendapat persentase sebanyak 79,36\%, dengan kriteria cukup layak.

\section{Kesesuaian Contoh, Fitur, dan Pelatihan}

Kesesuaian contoh, fitur, dan pelatihan dalam buku teks Bahasa Indonesia kelas XII SMA/MA/SMK/MAK terbitan Kementrian Pendidikan dan Kebudayaan edisi revisi 2018 
mendapatkan persentase sebanyak 88,09\%, Meski demikian, berdasarkan analisis yang dilakukan, buku ini memuat beberapa contoh wacana (teks) yang sudah cukup lampau. Hal tersebut disebabkan oleh tahun cetakan pertama pada 2015 silam, sehingga contoh-contoh yang digunakan belum up to date. Meskipun tidak terlalu berpengaruh dalam penyampaian makna materi, penggunaan contoh yang tidak disesuaikan dengan perkembangan zaman kurang efisien. Hal ini dapat dilihat pada Bab I halaman 3, mengenai contoh surat lamaran pekerjaan di mana surat lamaran pekerjaan yang digunakan adalah surat tahun 2008 , sedangkan buku teks yang diteliti sudah mengalami revisi pada tahun 2018.

\section{Pengembangan Penalaran dan Pembuktian}

Berdasarkan analisis yang dilakukan, diketemukan hasil bahwa materi tersaji dalam buku ini runtut dan tidak tumpang tindih. Selain itu, materi juga memuat soal-soal yang memiliki tingkat kesulitan bervariasi dan tidak diulangi secara berlebihan. Secara umum, materi dan soal yang terdapat dalam buku teks ini dimulai dari konsep yang mudah menuju konsep yang sukar, sederhana menuju kompleks, dan dari konkret menuju abstrak. Butir komponen ini mendapatkan persentase sebanyak $92,85 \%$ dan masuk dalam kategori sangat layak.

\section{Keterkaitan antara Konsep /Tabel/Diagram/Soal}

Peta konsep yang terdapat pada setiap bab memiliki fungsi untuk membantu siswa memahami cakupan materi yang akan dipelajari. Secara umum, butir komponen ini mendapatkan persentase sebesar $88,09 \%$ dan masuk dalam predikat sangat layak. Namun, terdapat beberapa hal yang kurang sesuai dengan konsep pembahasan. Hal ini terepresentasi pada Bab II, misalnya. Pada bab ini terdapat kekurangan yakni poin kegiatan yang dicantumkan tidak lengkap.

\section{Komunikasi (Write and Talk)}

Terdapat tiga indikator yang harus diperhatikan dalam buku teks. Adapun ketiga indikator tersebut sesuai dengan BSNP (2014) yaitu (1) materi menyediakan tugas atau kegiatan yang mendorong peserta didik untuk mengomunikasikan ide mereka dalam berbagai bentuk secara tertulis (individu, berpasangan, berkelompok), (2) materi menyediakan tugas atau kegiatan yang mendorong peserta didik mengomunikasikan ide dalam berbagai bentuk secara lisan (individu, berpasangan, berkelompok), (3) materi memuat tugas yang mendorong peserta didik untuk mencari dan memeroleh informasi melalui gagasan lisan maupun tulisan.

Ada beberapa indikator yang tidak ada di dalam buku teks yang dianalisis. Pada Bab I Menulis Surat Lamaran Pekerjaan tidak ditemukan secara eksplisit ketiga indikator yang telah disebutkan di atas. Pada Bab III Memahami Isu Terkini Lewat Editorial dan Bab IV Menikmati Novel tidak ditemukan tugas atau kegiatan yang mendorong peserta didik untuk mengomunikasikan idenya dalam berbagai bentuk secara lisan. Namun, bab lain yang tidak disebutkan di atas sudah mengandung indikator yang dicari pada butir komponen ini.

\section{Pembudayaan Literasi}

Berdasarkan (BSNP (2014), pembudayana literasi yang harus ada adalah, (1) materi memuat tugas yang mendorong siswa mencari informasi lebih lanjut dari berbagai sumber lain seperti laman internet, buku, serta artikel; (2) materi memuat tugas instruksional yang mendorong siswa aktif dan kritis menganalisis teks (literasi kritikal).

Indikator pertama sudah ditemukan pada banyak sekali materi, seperti pada Bab I yang terdapat instruksi yang mengarahkan siswa untuk menyusun surat lamaran pekerjaan dengan memilih dari berbagi sumber. Lalu pada Bab III, yang memuat tugas yang mengarahkan siswa untuk mencari sebuah teks dari surat kabar lokal atau nasional. Lalu, indikator kedua mengenai literasi kritikal, hal ini sudah ditemukan hamper di keseluruhan bab, yang mana termuat tugas yang mendorong siswa untuk aktif-kritis dalam menganalisis sebuah teks sesuai materi. 


\section{Pengembangan Wawasan Kebhinekaan, Kebangsaan, dan Intergrasi Bangsa}

Butir komponen pengembangan wawasan kebhinekaan, kebangsaan, dan integrasi bangsa memiliki dua indikator penting. Adapun kedua indikator yang sesuai dengan (BSNP (2014) adalah, (1) wawasan kebhinekaan: materi, pelatihan, contoh, dapat membuka wawasan peserta didik untuk mengenal, menghargai perbedaan budaya, adat dan peninggalan leluhur budaya bangsa; dan (2) wawasan nasionalisme: materi, pelatihan, atau contoh melahirkan kesadaran untuk bangga menggunakan bahasa Indonesia, membangkitkan rasa kebersamaan, membangun nasionalisme dan memperkuat identitas bangsa Indonesia. Berdasarkan hasil penelitian, hampir semua indikator termuat dalam setiap bab buku teks ini.

\section{Memperhatikan Kode Etik Penulisan dan Hak Cipta}

Pengutipan, perujukan materi, dan penyisipan gambar yang ada dalam buku teks ini sudah mencantumkan sumber. Namun, hampir keseluruhan sumber yang digunakan tersebut tidak dicantumkan dalam daftar pustaka. Hal ini dapat dilihat pada Bab I halaman 10, Bab II halaman 35, 59, 73, 79, Bab III halaman 100, 105, serta masih banyak pengutipan, perujukan materi, dan penyisipan gambar di bab lain yang tidak mencantumkan daftar pustaka.

Kelalaian dalam menuliskan sumber referensi dapat dianggap sebagai pelanggaran yang serius dalam dunia akademik. Hal ini tentunya sudah diatur oleh Undang-Undang Nomor 19 Tahun 2002 tentang Hak Cipta, Pasal 12 Ayat (1). Oleh sebab itu, penulisan referensi dan daftar pustaka harus sesuai dengan kaidah yang telah ditentukan. Atas dasar tersebut, persentase untuk butir komponen memperhatikan kode etik penulisan dan hak cipta hanya mendapat 38,09\% saja.

\section{Bebas Masalah SARA, Pornografis/Bias Gender/Wilayah dan Profesi}

Menurut BSNP (2014), materi pembelajaran tidak boleh menyinggung sara, seperti (1) tidak menimbulkan masalah suku, agama, ras, dan antar golongan (SARA) dan pornografi, dan (2 tidak mendiskriminasi jenis kelamin, wilayah, dan profesi. Berdasarkan analisis yang dilakukan, diketemukan bahwa kedua indikator tersebut sudah sesuai dengan seluruh bab pada buku teks Bahasa Indonesia kelas XII SMA/MA/SMK/MAK terbitan Kementrian Pendidikan dan Kebudayaan edisi revisi 2018. Buku tersebut telah menyampaikan materi bersama wacananya tanpa memuat hal-hal yang bersifat negatif dan sensitif. Hal ini tentunya sesuai untuk membangun moral siswa.

\section{SIMPULAN}

Berdasarkan hasil analisis dan telaah yang dilakukan pada buku teks Bahasa Indonesia kelas XII SMA/MA/SMK/MAK terbitan Kementrian Pendidikan dan Kebudayaan edisi revisi 2018, diketemukan kesimpulan bahwa buku tersebut dalam kategori layak untuk digunakan dengan nilai persentase $84,48 \%$. Meskipun demikian, dalam buku ini masih terdapat beberapa indikator dalam butir komponen yang perlu diperbaiki atau direvisi lagi, karena terdapat komponen yang mengurangi tingkat efektifitas buku tersebut. Misalnya adalah kode etik penulisan dan hak cipta. Namun, secara umum buku ini sudah baik, hal itu terbantu oleh komponen lain yang memilki nilai tinggi. Ke depannya, pihak Kementrian diharapkan melakukan pembaruan revisi dengan lebih baik dan cermat lagi.

\section{UCAPAN TERIMA KASIH}

Terima kasih penulis sampaikan kepada Prodi Pendidikan Bahasa dan Sastra Indonesia, Fakultas Bahasa dan Seni, Universitas Pendidikan Ganesha, yang telah memfasilitasi pelayanan, sehingga penulis dapat melakukan penelitian ini. Serta, pada seluruh pengelola Journal of Digital 
Learning and Education, MO.RI Publishing, yang memberikan penulis kesempatan untuk menerbitkan jurnal ini.

\section{DAFTAR PUSTAKA}

Badan Standar Nasional Pendidikan (BNSP). (2014). Instrumen Penilaian Buku Teks Pelajaran Tahun 2014. http://bsnp-indonesia.org/2014/05/28/instrumen-penilaian-buku-teks-pelajaran-tahun2014. Diakses pada 13 April 2021.

Fujiawati, F. S. (2016). Pemahaman Konsep Kurikulum dan Pembelajaran dengan Peta Konsep bagi Mahasiswa Pendidikan Seni. Jurnal Pendidikan dan Kajian Seni, 1(1), 16-28.

Huda, D. N. (2014). Analisis Kesesuaian Materi Buku Teks Bahasa Indonesia Non-BSE dengan Standar Isi Bahasa Indonesia untuk SMP Kelas VII. Undergraduate Thesis. Universitas Negeri Yogyakarta.

Husen, S. (2013). Pemilihan dan Pemanfaatan Buku Teks Mata Pelajaran Sejarah SMA Negeri 2 Probolinggo. Undergraduate Thesis. Universitas Jember.

Ikhsan, K. N., \& Hadi, S. (2018). Implementasi dan Pengembangan Kurikulum 2013. Jurnal Edukasi (Ekonomi, Pendidikan dan Edukasi, 6(1), 193-202. http://dx.doi.org/10.25157/je.v6i1.1682

Imamah, N. A. A., Artawan, G., \& Wisudariani, N. M. R. (2019). Analisis Kualitas Buku Teks Cerdas Berbahasa Indonesia untuk SMA/MA Kelas XI Terbitan Erlangga. Jurnal Pendidikan Bahasa dan Sastra Indonesia Undiksha, 9(1), 1-12.

Kementerian Pendidikan dan Kebudayaan. (2018). Bahasa Indonesia kelas XII SMA/MA/SMK/MAK (Edisi revisi 2018). Jakarta: Kementerian Pendidikan dan Kebudayaan.

Mislia, M. (2018). Kelayakan Buku Teks Bahasa Indonesia Kelas VIII di MTs Kabupaten Malang (Sebuah Kajian Berdasarkan BSNP). Thesis. Direktorat Program Pascasarjana Universitas Muhammadiyah Malang.

Prasetyo, N. (2021). Pentingnya Media Pembelajaran dalam Proses Belajar Mengajar di Sekolah. www.lpmgorontalo.kembikbud.go.id/2021/05/01/pentingnya-media-pembelajaran-dalamproses-belajar-mengajar-di-sekolah. Diakses pada 13 April 2021.

Prastowo, A. (2011). Metode Penelitian Kualitatif dalam Perspektif Rancangan Penelitian. Yogyakarta: Ar Ruzz Media.

Rista, K., \& Ariyanto E.A. (2018). Pentingnya Pendidikan dan Meningkatkan Motivasi Belajar Anak. Jurnal Abdikarya, 1(2).

Santoso, S., Agustini, N. L. P. E \& Tantri, A. D. S. (2021). Moral Analysis in The Videos of Dongeng Kita Channel and Its Relevance to Indonesian Learning. Al Islah: Jurnal Pendidikan, 13(1). https://doi.org/10.35445/alishlah.v13i1.441

Santoso, S. \& Dewi, N. K. S. (2021). Indonesian Language Learning Through Whatsapp Group To Build Interactive Learning Conditions. Journal of Digital Learning and Education, 1(1). https://doi.org/10.52562/jdle.v1i01.27

Sari, I. (2019). Kelayakan Buku Teks Bahasa Indonesia Kelas XI SMA/MA/SMK/MAK Edisi Revisi 2017: Analisis Isi, Bahasa, dan Penyajian. Undergraduate Thesis. Universitas Negeri Semarang. 
Siagian, B. A. (2016). Analisis Kesesuaian Isi Buku Teks Bahasa Indonesia Berbasis Kurikulum 2013. Suluh Pendidikan FKIP-UHN. 3(1), 77-87.

Sriasih, S. A. P. (2014). Modul Telaah Buku Teks. Singaraja: Universitas Pendidikan Ganesha.

Tarigan, G.H. \& Djago, T. (2009). Telaah Buku Teks Bahasa Indonesia. Bandung: ANGKASA.

Undang-Undang Nomor 19 Tahun 2002 tentang Hak Cipta.

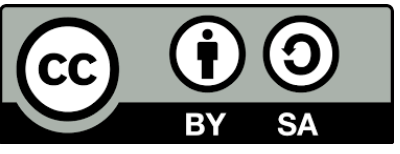

Copyright (c) 2021 by the authors. This work is licensed under a Creative Commons Attribution-ShareAlike 4.0 International License. 